\title{
Ethnic undercurrent and macro-level determinants of voter participation in Ghana's 2012 election: Implications for the 2020 national elections
}

\author{
Seidu Mahama Alidu \\ Senior Lecturer \\ Department of Political Science \\ University of Ghana, Legon \\ E-mail:smalidu@ug.edu.gh

\section{Gbensuglo Alidu Bukari} \\ Lecturer \\ Department of Politics and Government \\ University for Development Studies, Tamale \\ E-mail: gbensuglo@yahoo.com
}

Submitted: August 10, 2020 / Accepted: December 8, 2020 / Published: December 30, 2020

\begin{abstract}
In this paper we analyze the ethnic undercurrent and macro-level determinants influencing voter participation in Ghana based on aggregate district-level data. The paper focuses on the determinants that influenced citizens' political participation in the 2012 Presidential elections of the Fourth Republic of Ghana and their implications for the December 2020 national elections. The unique approach of this paper is that district-level aggregate data on economic characteristics compiled by the Ghana Statistical Service are synchronised with district-level national presidential election results compiled by the Electoral Commission of Ghana to ascertain the determinants of participation. The analysis is based on the concept of the "Average District Voter" which is analyzed using district-level census data combined with national election results. Statistical analysis was used to complementarily assess the determinants of voter participation in the Ghanaian 2012 presidential elections. The results of the analysis thus established two major points; that ethnic identification with regard to the two major ethnic groups in Ghana (i.e., the Asantes and the Ewes) has clearly influenced voter turnout, and second, that worsening socio-economic conditions played a role in voter turnout in the 2012 presidential elections and these issues will ultimately determine the winner of the 2020 national elections.
\end{abstract}

Legon Journal of the Humanities 31.1 (2020)

Page $\mid 145$ 
Keywords: Voter participation, ethnic voting, Ghanaian elections, macro-level analysis, socio-economic dynamics

\section{Introduction}

Ghana has a chequered political history marked by political independence, democratic gains and accompanying reversals instigated by numerous coups and counter coups afterwards (Anaman, 2016; Bukari, 2017, Anaman and Bukari, 2019). As a result, the 1980s and early 1990s were characterised by a concerted effort to revert the country back to electoral democracy. Significantly, this period coincided with the "Third Wave" of democratisation that had eroded despotic and other unconstitutional systems of governance worldwide (Huntington, 1991). The Third Wave of democratisation reintroduced open political systems and political competition in most African countries and the clarion demand by the citizens of these countries to participate in deciding who lead them and the decisions those leaders make. These demands began to entrench electoral democracy back to the political discourse of a continent hitherto obsessed with military and personal rule, albeit with some resistance from the military and political elite. Earlier studies on this transition, especially the determinants of voter behaviour, emphasised the salience of ethnicity and clientelism (Frempong, 2006, Cheeseman, et.al 2007, Chandra, 2009) while later studies examined multiplicity of explanatory models including ideology, retrospective and rational voting models (Lindberg, 2013; Lindberg and Morrison 2005, 2008; Alidu, 2017; Alidu and Aggrey-Darkoh, 2018).

However, beyond these macro-level dynamics, political participation is critical in determining voter dynamics and outcomes, especially in a majoritarian electoral system practiced in many African emerging democracies including Ghana which happens to be the case for this study. Our case selection is informed by multiplicity of factors of which two are more crucial. 
First, Ghana is a unitary state but multi-party and multi-ethnic in character. Ghana's multiparty trait is purely de jure because it has always been, politically and electorally, a duopolistic state since the passage of the Avoidance of Discrimination Act in 1957. The Avoidance of Discrimination Act (C.A, 38) was passed by the country's independence president, Kwame Nkrumah, to prohibit sectional parties based on racial, religious and regional differences. As a result, all other political organisations, except the CPP, morphed into the United Party thereby creating the CPP and UP traditions. This duopoly is reinforced in the Fourth Republic by the National Democratic Congress (NDC) and the New Patriotic Party (NPP) along the ideological lines of the 1957 political evolution creating an acrimonious and often violent struggle for political power.

Since the beginning of the Fourth Republican dispensation, these two political parties have always won national elections and in the 2008, 2012 and 2016 presidential elections garnered around 97 percent of the total valid votes cast (Bukari, 2017; Anaman and Bukari, 2019). Second, ethnicity is a major driver of electoral outcomes in Ghana (Anaman and Agyei-Sasu, 2012, Anaman, 2016) and an increasingly dangerous setback for democratic development when it is instrumentally expressed (Frempong, 2006). According to Anaman (2016, pp. 3-4) "national elections since December 2000 have revealed deeply-seated polarised, ethnically-based multi-party politics characterised by permanent electioneering campaigns, constant agitations and strikes organised by main opposition parties (NPP or NDC) with negative societal outcomes and consequences including effects on national and societal cohesion." The acrimonious duopolistic electoral system, coupled with an instrumentalist ethnic-induced electoral campaigns, continue to undermine independent and popular democratic participation in Ghana. Since the return to multiparty democracy in 1992, the country has witnessed relatively peaceful elections in its seventh series of national presidential and parliamentary 
elections. In other countries, the toxic combination of these two challenges have led to major electoral violence and war. Yet, in Ghana, these have become sources of mobilisation and voter turnout. This presents a conundrum. Thus, the main objective of this paper is to establish the factors that influenced voter participation (turnout) in the 2012 presidential election. The rest of the paper is structured as follows: the next section deals with the theoretical framework, followed by the methodology and the results are then discussed in the next two sections. This is followed by the conclusion and recommendation.

\section{Theoretical framework}

The literature on voting behaviour is one of the oldest subjects in political science and as such has generated enormous amounts of scholarly attention (Lindberg, 2013; Lindberg and Morrison 2005). The huge nature of the literature on the subject presents a challenge in determining electorate's preferences in a closely contested and multi-issue-based elections (Alidu, 2015). Even though different theories could underpin our current study which focuses on ethnicity and macro-level determinants of voter behaviour in Ghana, two of these theories stand out. These are the sociological and rational choice theories.

The sociological theory of voter behaviour explains voters' preferences in an election in relation to identities (i,e., ethnic, religious, geographical location, etc), appearances (handsome, ugly, tall, short), mannerism, attitude and other sociological attributes (Alidu, forthcoming). Identities are assumed to be the dominant determinant of voter behaviour in sub-Saharan Africa (Ichino and Nathan, 2013; Ishiyama, 2011; Horowitz, 1985 and Elischer, 2012). For example, Ishiyama (2011) sees elections in Africa as "ethnic-driven"; Horowitz (1985) refers to same as "ethnic census" where electorate vote to register their membership of an ethnic group. Elischer (2012) notes that voting in Africa is mostly confined to "communal boundaries" (p. 643) and also issues related to identity such 
as ethnicity, religion and geography. Heywood (2007) broadly labels these explanations as the sociological model of voting behaviour.

In Ghana, studies on voting behaviour conclude that ethnicity and other sociological variables play significant roles in the outcome (Alidu, 2018; Anebo, 2006; Frempong, 2014, 2016). Identity factors influence the choice of flag bearers and running mates in both the NDC and the NPP; the two leading political parties in Ghana (Alidu, forthcoming). When the flagbearer is a Southerner, a Christian and Akan; the running mate is likely going to be a Northerner, a Muslim and Dagomba/ Gonja/Mamprusi. This is seen largely as "balancing the ticket" (Alidu, forthcoming). Principally, the assumptions of the sociological theory have become the basis for the selection of leaders in almost all the political parties in the country.

Though this has been working over the years for the dominant political parties, focusing on the sociological theory alone as an explanatory framework can potentially ignore other significant factors that inform voting behaviour in the country. The rational choice theory is adopted to complement the shortfalls of the sociological theory in explaining voting behaviour in Ghana.

The rational choice theory has been used widely to explain voting behaviour across the world. The rational choice theory explains voting behaviour as a calculated act where electorates decide who to vote for based on certain assumptions. In the rational choice theory, a candidate's competence, skills, qualifications, track-record and capacity could be a basis for voters' decision to repose confidence in him/her (Alidu and Aggrey-Darkoh, 2018). Rationality could also manifest in the form of anticipated benefits that electorate may get when they vote in a certain way (Alidu and Aggrey-Darkoh, 2018). In most established democracies, electorates are influenced by the expected benefits of their electoral choice (Downs, 1957; Ayee, 2011). Explaining this phenomenon in Ghana, Bob-Millar 
(2012) argues that rational supporters of political parties see their support as a form of "investment" that will yield "selective incentives base on the amount of one's contribution to the party" (p. 681).

Indeed, the rational choice theory is seen to encompass all other theories of voting behaviour since all the other theories have rational undercurrent (Ishiyama, 2012; Chandra, 2004; Posner, 2004, 2005; and Ferree, 2006. For example, Ishiyama (2012) argues that voters are rational in thinking that leaders "who are members of their own ethnic or tribal community [(and by extension religious or regional area)] are more likely to dispense patronage to them than leaders who are not" (p. 764). Bob-Millar (2012) also arrives at a similar conclusion in his explanation of the incentives that determine the selection of party membership by the youth in Ghana. Conclusively, rationality and the rational choice theory underpin voter decisions that might have been explained by other theories (Gyampo and Debrah, 2013; Ayee, 2012 and Obeng-Odoom, 2013). Therefore, the majority position is that voters elect candidates and political parties based on rational calculations; especially voter population that is largely undecided.

\section{Literature review on voter participation}

Modern political liberalism is based on the principle of equality of all citizens to participate in the managing of political affairs, and that every citizen's input is of equal importance. This right is embedded in the principles of democratic governance, and enshrined in the constitution of nation-states. In modern liberal democracy, this fundamental right place emphasis on citizens' political participation in order to maintain a stable democracy (Norris, 2002). However, the level of citizens' participation in politics is debatable with some scholars arguing that "too much public participation would overwhelm and ultimately cripple democratic systems" (Vowles, 1995, p. 151). Other scholarly discussions favour high level of political participation, arguing 
that "more citizen involvement leads to greater representation" (ibid, p. 151).

Though political participation remains a critical benchmark in modern democratic governance, the processes leading to citizens' participation vary, and depend on the political system as well as the method used to influence political decision making. Vowles (1995, p. 151) argues that "method of political participation is key in controlling public influence over political affairs, and therefore is also an integral part of maintaining democracy, whether it be 'thin' (low levels of participation) or 'robust' (high levels of participation)." It is argued that "a high level of political participation or 'robust' democracy enhances democracy through providing the opportunity for more issues to be represented during decision making" (Vowles, 1995, p. 137). Political participation is expressed as the 'general will' of the people and as McAllister (1992) argues, "there should be equal participation by all citizens, and that education was a key component in raising awareness of civic duty and obligation" (p. 51-53). Also, proponents of popular political participation, "feared tyranny of the majority, and therefore sought to devise mechanisms to control participation in order to avert any potential tyrannical tendencies" (McAllister, 1992, pp. 52-53). Some scholars devised political participation control mechanisms as "plural voting for the educated, literacy tests for voter eligibility and restrictions of votes to taxpayers," other scholars "pursued pluralism through the decentralization of power, and the promotion of public participation through interest groups, voluntary organizations and other associations that allowed for local decision-making" (Tocqueville, 1990, p. 323).

Conversely, while these theories promote increased public participation, there are others that advocate for limited participation. For instance, those in favour of limited participation in democratic discourse argue that, "high levels of citizen participation can saturate political leaders with demands that they should not and cannot meet, therefore putting pressure 
on the political system" (Vowles, 1995, p. 137). This school of thought reasons that instead of high level of participation by citizens, democracy can rather be maintained through elite competition. The argument is that many citizens and voters are often socialized through their families, and many have little knowledge of policy, parties and candidates (Schumpeter, 1954). Bachrach (1967, p. 32) for example, argues that "government is best left for those elites who are knowledgeable about political affairs; those with little knowledge about politics should be discouraged from voting; and stable democracies are those where there is little public participation, favouring public apathy over activism." Yet, there is a general acceptance that "there should be some level of participation in order to ensure stable democracy, as of course the notion itself is founded on the premise that all citizens be able to input into political decision making" (Tocqueville, 1990, p. 323).

Political participation is also explained in the context of choice making by citizens' in an election and also by resource availability. Arguably, one of the most relevant theories of voter behaviour in political science and which speaks to citizens' right to choose, is the rational choice theory. Downs (1957), in his seminal work on rational choice theory, argues that citizens decide to vote if the "benefit of voting outweighs the cost". Riker and Ordeshook (1968) extend this theory by stating that " ... the net benefit of voting to any individual is equal to the benefits of the preferred election outcome to that individual times the probability that his or her vote will affect that outcome less the cost of voting, or R = BP-C (Franklin, 2004, p. 38). Riker and Ordeshook's (1968) model assumes "that the only benefits of significance are those benefits to the individual who is considering the act of voting" (ibid, p. 38). Concerning resource availability, the resource model argues that "political participation is dependent on resources at the disposure of the individual" (Brady et al, 2004, pp. 271-294). Resources deemed essential in this respect include "time, money 
and civic skills" and these could dictate how, and to what extent, individuals choose to participate politically. In essence, the resource availability theory argues that "differential access to resources ultimately results in some citizens possessing more political influence than others" (McAllistair, 1992, p. 55). A typical example is the difference in resource between a literate and an illiterate citizen in a democracy. While the literate citizen possesses civic skills to enable him/her to read, understand and influence the political system, the illiterate citizen lacks civic skills and its corresponding powers. On the other hand, an uneducated but wealthy citizen who has much time could use both the wealth and time to influence decision making.

Political participation also has relevance in the model of psychological involvement. This model explains that participating in politics depends on citizens' interest. That is the 'more interested a person is in politics, the more likely they are to participate in the political discourse. Further, the theory of mobilization (Rosenstone and Hansen, 1996) also explains why people participate politically. Rosenstone and Hansen (1996, p. 42) argue that a "citizen cannot be viewed in isolation, and that their social networks including friends, family, community, neighbours, co-workers, political parties, activists and interest groups must all be taken into account." Individuals are seen as "being under pressure to behave as members of a group, and therefore participate politically as required by that particular network" (Rosenstone and Hansen, 1996, pp. 22-24). Individuals are mobilized both directly and indirectly by political parties and social networks. This is closely related to the 'social-learning' model that argues that cultural factors are significant influences on political participation, and that individuals are socialized to behave in a certain way (Rosenstone and Hansen, 1996). This particular model has two distinguishable strands. The first argues that there is "social pressure placed on an individual to behave or participate in a certain way (which is similar to the mobilization model)," and the second "encapsulates a sense of duty to support 
the well-being of their communities or networks" (Rosenstone and Hansen, 1996, pp. 22-24).

However, Blais (2000) argues that "it is this model that directly challenges the rational choice theory, as it is based on the notion that individuals do not act in their own self-interest (as rational theory implies) but rather for a collective interest (again, as related to the mobilization model), and are also socialized to behave or participate in a certain way" (p. 24). This could be true for Ghanaian political participation, hence, the need to examine factors of political participation. Franklin (2004, pp. 59-90) advanced an interesting "thesis on generational change and voter turnout." He argues that "the experience of new voters will affect life-long voting behaviour." In this regard, scholars have argued that "if an individual votes the same way three times in a row, it is likely that the individual will become resistant to changing their voting behaviour" and that "the experience of new voters in their first few elections will dictate their future behaviour" (ibid, 2004, pp. 59-90). Though this theory is based on 'voter turnout' and 'voting behaviour,' it has an interesting implication for political participation.

\section{Methodology}

In this paper, we are concerned about the voter turnout ratio or rate in the 2012 presidential elections held in Ghana, and will therefore be testing for that dependent variable. In the literature, the voter turnout ratio is normally assumed to be the total number of registered voters who actually voted in an election expressed in fraction or percentage terms. An alternative measure of the voter turnout ratio is expressed as the total number of people who actually voted in an election as a percentage of the voting age population (Blais, 2000; Blais et. al., 2004). The alternative measure of the voter turnout rate arises partly from over bloated registers or registers that contain many people who are not qualified to vote, either by age or 
through other circumstances.

In Ghana, eligible voters (voting population) have been defined to include all citizens that are within, and above the legal voting age of 18 years and above as required by law. ${ }^{1}$ In the analysis adopted for this paper, the social and economic characteristics that influence the voter turnout ratio are determined using the 2012 national presidential elections, and the corresponding 2010 Population Censuses. The voter turnout ratio, like all ratios in mathematics, is defined as the numerator divided by the denominator. The numerator for a voter turnout ratio is always the total number of votes actually cast in an election in a specific geographical area.

However, the denominator varies for voter turnout ratios due to the possibility of over-registration or bloated electoral registers. For this paper, the voter turnout ratio is defined using two measures. These are (1) the total number of people who voted in the election at the district level (numerator) divided by the total number of people registered to vote at the district level based on data from the Electoral Commission of Ghana for district $\mathrm{i}$ (the first denominator) specified in this paper as TURNOUTA; (2) the total number of people who voted in the election at the district level (numerator) divided by the total number of people aged 15 and over in the district based on the Census data (the second denominator) specified in this paper as TURNOUTB (Chan and Clayton, 2006). ${ }^{2}$

\section{Measuring macro-level voter participation in the 2012 general elections}

The first voter turnout ratio model is expressed as a multiple regression equation as follows in Equation 1 with

\footnotetext{
1 The official definition of voting age in Ghana is 18 years and above (i.e. citizens who are eighteen years and above are eligible to register and vote in all public elections in Ghana, and to be voted for) as stated in (Article 42, 1992 Constitution: 43) of the 1992 Fourth Republican constitution of Ghana.

2 This study used age 15 and over as an alternative 'measure of turnout' to deal with the over bloated electoral register as was observed in the 2012 General elections (See Chan \& Clayton, 2006). Should the voting age be lowered to sixteen? Normative and empirical consideration of voting age, Political Studies, (54) pp. 533-558.
} 
12 independent variables assumed to influence the dependent variable.

TURNOUT2012 $\mathrm{A}_{\mathrm{i}}=\mathrm{B}_{0}+\mathrm{B}_{1}$ LITERACY $_{\mathrm{i}}+\mathrm{B} 2$ EMPLOYPROP $_{\mathrm{i}}+\mathrm{B}_{3}$ URBANPROP $_{\mathrm{i}}+\mathrm{B}_{4} \mathrm{AGEDR}_{\mathrm{i}}+$ B $_{5}$ ASANTEPROP $_{\mathrm{i}}+\mathrm{B}_{6}$ EWEPROP $_{\mathrm{i}}+\mathrm{B}_{7}$ HOUSEHOLDSIZE $_{\mathrm{i}}$ $+\mathrm{B}_{8}$ REGISTEREDVOTERS $_{\mathrm{i}}+\mathrm{B}$ MUUSLIMi $+\mathrm{B}_{10}$ CHRISTIAN $_{\mathrm{i}}+\mathrm{B}_{11}$ SEXRATIO $_{\mathrm{i}+} \mathrm{B}_{12}$ DISABILITYRATIO $_{\mathrm{i}}+$ Ui...................................Equation (1)

Where:

TURNOUT2012 $\mathrm{A}_{\mathrm{i}}$ is the dependent variable and is a ratio which is defined as the total number of people who voted in the 7 December 2012 national presidential election at the district level divided by the total number of people registered to vote at the district level based on data from the Electoral Commission of Ghana for district i;

LITERACY $_{\mathrm{i}}$ is a continuous variable measuring the proportion of the population in district $i$ who have formal educational qualifications based on data from the September 2010 National Population Census;

EMPLOYPROP $_{i}$ is a continuous variable measuring the proportion of population in the district $i$ who describe themselves as employed based on the September 2010 National Population Census data;

URBANPROP $_{\mathrm{i}}$ is a continuous variable measuring the proportion of the population in the district $i$ who reside in urban areas, as defined by the Ghana Statistical Service as those towns and settlements with population of more than 5,000 people, using the September 2010 National Population Census data;

$\mathrm{AGEDR}_{\mathrm{i}}$ is the dependency ratio for the district $\mathrm{i}$ defined as 
the number of people aged between zero to 14 plus the number of people aged 65 and above divided by the number of people aged between 15 and 64. The dependency measure is a useful measure of poverty with increasing age dependency signalling higher burden on the working population to take care of the very young and the very old people who are assumed not to be actively working;

ASANTEPROP $_{i}$ is a continuous variable defined as the proportion of the population in district $i$ who consider themselves to be Asantes based on the September 2010 National Population Census data. Asantes constitute about one third of all Akans and are modelled as a distinct voting group different from the other Akans;

EWEPROP $_{\mathrm{i}}$ is a continuous variable defined as the proportion of the population in district $\mathrm{i}$ who consider themselves to be Ewes based on the September 2010 National Population Census data;

HOUSEHOLDSIZE $_{i}$ is the average number of members per household in district $\mathrm{i}$ based on the September 2010 National Population Census data;

REGISTEREDVOTERS $_{\mathrm{i}}$ is a continuous variable indicating the number of people registered as voters in the district $i$ for the December 2012 national presidential election, measured in thousands. The main registration of voters by biometric means was undertaken in mid-2011 just nine months after the start of the September 2010 National Population Census and around the time the Census data were being finalised;

MUSLIM $_{\mathrm{i}}$ is a continuous variable measuring the proportion of the population in district $\mathrm{i}$ who describe them as Muslims based on the September 2010 National Population Census data; CHRISTIAN $_{i}$ is a continuous variable measuring the proportion 
of the population in district $\mathrm{i}$ who describe them as Christians based on the September 2010 National Population Census data;

SEXRATIO $_{i}$ is a continuous variable measuring the number of females divided by the number of males in district $i$ based on the September 2010 National Population Census data;

DISABILITYPROP $_{i}$ is a continuous variable measuring the proportion of population in district $\mathrm{i}$ classified as disabled based on the September 2010 National Population Census data;

$\mathrm{U}_{\mathrm{i}}$ is the regression equation error term initially assumed to be normally distributed with zero mean and constant variance.

The second voter turnout ratio model is expressed as a multiple regression equation as follows in Equation 2 with 12 independent variables assumed to influence the dependent variable.

TURNOUT2012 $\mathrm{B}_{\mathrm{i}}==\mathrm{B}_{0}+\mathrm{B}_{1} \quad$ LITERACY $_{\mathrm{i}}+\mathrm{B}_{2}$ EMPLOYPROP $_{\mathrm{i}}+\mathrm{B}_{3}$ URBANPROP $_{\mathrm{i}}+\mathrm{B}_{4}$ AGEDR $_{\mathrm{i}}+$ $\mathrm{B}_{5}$ ASANTEPROP $_{\mathrm{i}}+\mathrm{B}_{6}$ EWEPROP $_{\mathrm{i}}+\mathrm{B}_{7}$ HOUSEHOLDSIZE $_{\mathrm{i}}$ $+\mathrm{B}_{8}$ POP15ANDOVER $_{\mathrm{i}}+\mathrm{B}_{9}$ MUSLIM $_{\mathrm{i}}+\mathrm{B}_{10}$ CHRISTIAN $_{\mathrm{i}}$ $+\mathrm{B}_{11}$ SEXRATIO $_{\mathrm{i}}+\mathrm{B}_{12} \quad$ DISABILITYRATIO $_{\mathrm{i}}+$

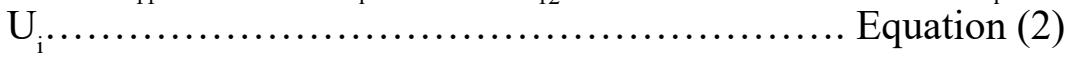

Where:

TURNOUT2012 $\mathrm{B}_{\mathrm{i}}$ is defined as the total number of people who voted in the 2012 presidential election at the district level divided by the total number of people in the district who are aged 15 and over. It is used as an alternative measure of turnout ratio for the purpose of this study to deal with the highly-bloated electoral register which was observed for the 2012 national presidential election (refer to Appendix 4 for data on statistical bloating of the voter register for the 2012 election);

LITERACY $_{i}$ is a continuous variable measuring the proportion

Legon Journal of the Humanities 31.1 (2020) Page 158 
of the population in district $\mathrm{i}$ who have formal educational qualifications based on data from the September 2010 National Population Census;

EMPLOYPROP $_{i}$ is a continuous variable measuring the proportion of population in the district $i$ who describe themselves as employed based on the September 2010 National Population Census data;

URBANPROP $_{\mathrm{i}}$ is a continuous variable measuring the proportion of the population in the district $i$ who reside in urban areas, as defined by the Ghana Statistical Service as those towns and settlements with population of more than 5,000 people, using the September 2010 National Population Census data;

$\mathrm{AGEDR}_{\mathrm{i}}$ is the dependency ratio for the district $\mathrm{i}$ defined as the number of people aged between zero to 14 plus the number of people aged 65 and above divided by the number of people aged between 15 to 64; the dependency measure is a useful measure of poverty with increasing age dependency signalling higher burden on the working population to take care of the very young and the very old people who are assumed not to be actively working;

ASANTEPROP $_{i}$ is a continuous variable defined as the proportion of the population in district $\mathrm{i}$ who consider themselves to be Akan-Asantes based on the September 2010 National Population Census data;

EWEPROP $_{\mathrm{i}}$ is a continuous variable defined as the proportion of the population in district $i$ who consider themselves to be Ewes based on the September 2010 National Population Census data;

HOUSEHOLDSIZE $_{i}$ is the average number of members per household in district $\mathrm{i}$ based on the September 2010 National 
Population Census data;

POP15ANDOVER $_{i}$ is a continuous variable indicating the number of people in the district $\mathrm{i}$ who are aged 15 and over, measured in thousands, based on the September 2010 National Population Census data;

MUSLIM $_{\mathrm{i}}$ is a continuous variable measuring the proportion of the population in district $\mathrm{i}$ who describe them as Muslims based on the September 2010 National Population Census data;

CHRISTIAN $_{\mathrm{i}}$ is a continuous variable measuring the proportion of the population in district $i$ who describe them as Christians based on the September 2010 National Population Census data;

SEXRATIO $_{\mathrm{i}}$ is a continuous variable measuring the number of females divided by the number of males in district $i$ based on the September 2010 National Population Census data;

DISABILITYPROP $_{i}$ is a continuous variable measuring the proportion of population in district $\mathrm{i}$ classified as disabled based on the September 2010 National Population Census data.

$\mathrm{U}_{\mathrm{i}}$ is the regression equation error term initially assumed to be normally distributed with zero mean and constant variance.

\section{Results and Discussion}

\section{Results of the analysisinvolving the first voter turnout ratio regression model for the 2012 National Presidential Election in Ghana: First equation}

The summary of the results of the estimated regression of voter participation indicated by TURNOUT2012A is reported in Table 1 below. Overall, the model could be regarded as modestly strong with statistically significant $\mathrm{R}^{2}$ and $\mathrm{F}$ value. The estimated model was correctly specified based on the Ramsey Reset Test 
for correct specification with the $p$ value of 0.193 . This $p$ value is well above the maximum critical $p$ value of $5 \%$ used in this study. This meant that the null hypothesis that the model was correctly specified could not be rejected. The Langrange-Multiplier (LM) test for heteroscedasticity confirmed the absence of the problem of heteroscedasticity with $\mathrm{p}$ value of the test of 0.982 well above the critical $0.05(5 \%) \mathrm{p}$ value used in this study. The LangrangeMultiplier test of no heteroscedasticity regresses the square of the error term of the model equation against the square of the predicted value of the model equation. Finally, the variance inflation factor (VIF), a measure of multicollinearity in the model, was below the critical value of 10 , suggested by Gujarati (2003) for all the 12 independent variables, clearly indicating that the problem of multicollinearity did not exist in the model.

The estimated values of the specific parameters of the model are also reported in Table 1 for each of the 12 independent variables that were hypothesized to affect the voter participation defined by TURNOUT2012A. The general test of hypothesis is based on the framework that the independent variables significantly affect the variation in the dependent variable. The estimated parameters of the 12 independent variables and their Student $\mathrm{t}$ values and $\mathrm{p}$ values are reported in Table 1. Using the maximum acceptable level of statistical significance level of 5 percent (0.05) for this study, only ASANTEPROP, EWEPROP and HOUSEHOLDSIZE have their estimated parameters statistically significantly different from zero (or statistically significant) meaning that these variables exert statistically significant influence on the dependent variable (TURNOUT2012A).

The result linked to ASANTEPROP indicates that the voter turnout ratio in a district increases with increasing proportion of the population being Asantes. This result suggests increasing interest and vigour of Asantes in voting in the 2012 national presidential election. In contrast, the voter turnout ratio declines in a district with increasing proportion of the population 
being Ewes.

The other significant independent variable is the household size. With a positive value, this suggests that households with bigger numbers tend to participate more in voting possibly due to intra-household voter mobilisation.

The other nine variables do not influence the dependent variable in a statistically-significant manner. Of these variables, two have absolute values greater than 1.0 suggesting that they could not be dropped from the model because that would cause specification bias. These two variables are LITERACY and SEXRATIO.

The positive parameter sign for LITERACY suggests that with increasing literacy, voter turnout rate rises. The negative parameter sign for SEXRATIO indicates that voter turnout rates appear to decline with relatively higher female-male ratios in a geographical area. So, while these two variables are not statistically significant, their estimated parameters appear to be plausible.

Table 1 provides a summary of the results of the regression analysis of district-level socio-economic factors which influence voter participation as measured by TURNOUT2012A for the 2012 national presidential election in Ghana.

Dependent Variable is TURNOUT2012A defined as the total number of people who voted in the 2012 presidential election at the district level divided by the total number of people registered to vote at the district level based on data from Electoral Commission of Ghana. 
Table 1: Summary of the results of the regression analysis (TURNOUT201

\begin{tabular}{|l|c|c|c|c}
\hline $\begin{array}{l}\text { Explanatory } \\
\text { Variable }\end{array}$ & $\begin{array}{l}\text { Parameter } \\
\text { Estimate }\end{array}$ & $\begin{array}{l}\text { Standardised } \\
\text { Parameter } \\
\text { Estimate }\end{array}$ & $\begin{array}{l}\text { Student } \\
\text { t Value }\end{array}$ & $\begin{array}{l}\text { Probability Level of } \\
\text { Significance }\end{array}$ \\
\hline Constant & 62.851 & 0.000 & 3.149 & $0.002^{* * *}$ \\
\hline Literacy & 0.067 & 0.253 & 1.420 & 0.157 \\
\hline Employprop & 0.118 & 0.054 & 0.533 & 0.594 \\
\hline Urbanprop & 0.010 & 0.050 & 0.575 & 0.566 \\
\hline Agedr & 0.014 & 0.040 & 0.319 & 0.750 \\
\hline Asanteprop & 0.095 & 0.418 & 5.891 & $0.000 * * *$ \\
\hline Eweprop & -0.048 & -0.244 & -3.355 & $0.001 * *$ \\
\hline Householdsize & 0.834 & 0.256 & 2.428 & $0.016^{* *}$ \\
\hline Registeredvoters & -0.002 & -0.045 & -0.654 & 0.514 \\
\hline Muslim & -0.062 & 0.009 & 0.080 & 0.936 \\
\hline Christian & 0.243 & -0.006 & -0.034 & -1.091 \\
\hline Sexratio & -0.001 & 0.067 & 0.930 & 0.973 \\
\hline Disabilityprop & -0.061 & 0.354 \\
\hline
\end{tabular}

Notes on Table 1: Source: Ghana Statistical Service and Electoral Commission of Ghana, 2016 Legon Journal of the Humanities 31.1(2020) 
Valid Sample Size used for the analysis was 216 Administrative Districts

$\mathrm{R}^{2}$

F Value

Probability significance level of Ramsey Reset Test for correct model specification

Probability significance level of Langrange-Multiplier test of no heteroscedasticity

0.982

The Langrange-Multiplier test of no heteroscedasticity regresses the square of the error term of the model equation against the square of the predicted value of the model equation.

*** denotes statistical significance of the parameter at the $1 \%$ level.

** denotes statistical significance of the parameter at the $5 \%$ level.

Results of the analysis involving the second voter turnout ratio regression model for the 2012 National Presidential Election in Ghana: Second equation

The results of the estimated regression of voter participation rate, indicated by TURNOUT2012B, are summarized in Table 2 below. The model was correctly specified based on the Ramsey Reset Test with the $p$ value of 0.052 just above the 5 percent maximum margin used for this study. The LM test for heteroscedasticity confirmed the non-existence of the problem. Multicollinearity did not exist in the model with all the 12 independent variables having VIFs below the critical value of 10.0 (Guajarati, 2003). The estimated values of the specific parameters of the model are also reported in Table 6.2 for each of the 12 independent socio-economic variables that were hypothesized to affect the voter participation rate defined by TURNOUT2012B.

Only five of the 12 independent variables are significant. These are EMPLOYPROP, URBANPROP, AGEDR, 
ASANTEPROP and POP15ANDOVER. The negative parameter estimate linked to EMPLOYPROP indicates that the voter turnout ratio decreases with increasing proportion of the population employed. All things being equal, voter participation in the 2012 Presidential election tends to be lower with increasing proportion of people who are employed in a district. Again, there was an inverse relationship between the URBANPROP and voter participation in the 2012 Presidential election. This means that all things being equal, voter participation in the 2012 Presidential election decreases with increasing proportion of registered voters in urban centres or districts in Ghana.

Further, the negative sign linked to AGEDR means that voter turnout tends to decrease with increasing proportion of age dependency ratio (AGEDR) which measures the ratio of proportion of people who are dependants on the workforce in a district in Ghana. This suggests that districts with higher age dependency ratios tend to participate less in voting, a plausible outcome which also suggests that increasing poverty burden discourages participation in voting. Another significant independent variable is the Asante proportion in each district. The parameter estimate of this variable suggests that voter turnout tends to increase with increasing proportion of Asantes in a district in Ghana in the 2012 Elections. Finally, there was also an inverse relationship between voter turnout and POP15ANDOVER. This means that all things being equal, the voter turnout ratio declines in a district with increasing proportion of the population POP15ANDOVER in each district in the 2012 elections in Ghana.

This result is largely consistent with the findings in literature which suggests that voter turnout declines with increasing population density in industrial democracies (Gray and Caul, 2000). The other seven variables do not influence the dependent variable in a statistically-significant manner. Of these variables, three have absolute values greater than 1.0 suggesting that they could not be dropped from the model because that 
would cause specification bias. These three factors include the DISABILITYPROP, EWEPROP and MUSLIM. The most interesting finding related to the non-significant variables deals with DISABILITYPROP; this suggests a negative relationship between voter turnout rate and increasing disability ratio; this finding is clearly intuitive, though not significant, as disabled people find it more difficult to vote given the relatively less developed formal mechanisms and structures in Ghana that assist disabled people to vote.

Table 2 provides a summary of the results of the regression analysis of district-level socio-economic factors which influence voter participation as measured by TURNOUT2012B for the 2012 national presidential election in Ghana.

Dependent Variable is TURNOUT2012B defined as the total number of people who voted in the 2012 presidential election at the district level divided by the total number of people in the district who are aged 15 and over. 
Table 2: Summary of the results of the regression analysis (TURNOUT2012

\begin{tabular}{|l|l|l|l|l}
\hline $\begin{array}{l}\text { Explanatory } \\
\text { Variable }\end{array}$ & $\begin{array}{l}\text { Parameter } \\
\text { Estimate }\end{array}$ & $\begin{array}{l}\text { Standardised } \\
\text { Parameter } \\
\text { Estimate }\end{array}$ & $\begin{array}{l}\text { Student } \\
\text { t Value }\end{array}$ & $\begin{array}{l}\text { Probabili } \\
\text { Significa }\end{array}$ \\
\hline Constant & 310.312 & 0.000 & 4.063 & $0.000^{* * *}$ \\
\hline Literacy & 0.078 & 0.081 & 0.432 & 0.666 \\
\hline Employprop & -1.930 & -0.241 & -2.283 & $0.023^{* *}$ \\
\hline Urbanprop & -0.147 & -0.209 & -2.297 & $0.023^{* *}$ \\
\hline Agedr & -0.346 & -0.263 & -2.003 & $0.046^{* *}$ \\
\hline Asanteprop & 0.160 & 0.192 & 2.591 & $0.010^{* *}$ \\
\hline Eweprop & -0.069 & -0.096 & -1.261 & 0.209 \\
\hline Householdsize & -0.188 & -0.016 & -0.142 & 0.887 \\
\hline Pop15andover & -0.040 & -0.252 & -3.650 & $0.000 * * *$ \\
\hline Muslim & 0.093 & 0.121 & 1.083 & 0.280 \\
\hline Christian & -0.070 & -0.091 & -0.531 & 0.596 \\
\hline Sexratio & -0.099 & -0.035 & -0.450 & 0.654 \\
\hline Disabilityprop & -1.234 & -0.093 & -1.233 & 0.219 \\
\hline
\end{tabular}

Notes on Table 2:

Source: Ghana Statistical Service and Electoral Commission of Ghana, 2016

Legon Journal of the Humanities 31.1 (2020) 
Valid Sample Size used for the analysis was 216 Administrative Districts

$\mathrm{R}^{2}$

0.235

F Value

5.192

Probability significance level Ramsey Reset Test for correct model specification 0.052

Probability significance level of Langrange-Multiplier test of no heteroscedasticity 0.068

The Langrange-Multiplier test of no heteroscedasticity regresses the square of the error term of the model equation against the square of the predicted value of the model equation.

$* * *$ denotes statistical significance of the parameter at the $1 \%$ level.

** denotes statistical significance of the parameter at the $5 \%$ level.

\section{Implications of findings on the $\mathbf{2 0 2 0}$ general elections}

This section of the paper highlights the impact of ethnic sentiments as well as issues-based campaign (that determined the outcome of the 2012 elections) on the forthcoming national elections in 2020 specifically and Ghanaian electoral politics in general. The 2020 elections is the eighth in a series of presidential and parliamentary elections conducted in the country since the transition to electoral democracy in 1992. Unlike the previous seven elections, the 2020 election is different in several ways. The Covid-19 pandemic has affected the manner in which the 2020 elections will be conducted. Compared to previous elections, it has affected the mode of campaigning by both opposition and incumbent parties (Brierley and Kramon, 2020) and has the potential to affect voter turnout for fear of infection (Abdulai and Sackyefio, 2020). Corruption and the issue of corruptibility has been an electoral determinant since independence and has gained much currency in national elections since the Fourth Republic. One of the major factors that caused the defeat of the NDC in 
2016 was corruption (Alidu, 2017). While several allegations of corruption were levelled against the flagbearer of the NDC in the run up to the 2016 general elections, his counterpart in the NPP was hailed as incorruptible and a protector of the public purse (Alidu, 2017). The NPP government established the Office of the Special Prosecutor in fulfilment of its campaign promise to fight corruption. Few weeks to the general election this year, several events have forced corruption to the front burner as a major campaign issue, including the Airbus Scandal and the allegation that Government Official One is the former President and the NDC's flagbearer; the PDS scandal, the Agyapa Gold Royalties transaction, the Kroll and Associates transaction, the mandatory leave instruction from the government to the Auditor-General, Daniel Domelovo; and the resignation of Martin Amidu as the Special Prosecutor.

Another significant issue that will determine the outcome of the 2020 election is expansion in social development and infrastructure, including the social intervention programs currently being implemented. Examples include the Free Senior High School policy, Planting for Food and Jobs, One Village One Dam and the Livelihood Empowerment Against Poverty of the NPP and the Free TVET, the Big Push, Four Year Maternity Leave for Women, the Free Tertiary Education, Expansion of the Free SHS policy to Private Schools, among others, of the NDC. Social intervention policies have always influenced electoral outcomes in Ghana since independence. The formulation and implementation of these policies are heavily influenced by the ideological position of the political parties competing for political power. However, over the years, it is more politically expedient for either the NDC or NPP to promise anything that will win them political power irrespective of the ideological position of that policy in the party.

Several other issues are assumed to be of great significance, to the outcome of the 2020 election, including the financial sector crisis, the debate on infrastructure, the NDC's 
selection of a female running mate, the fight against illegal mining and the attendant consequences, among others (Abdulai and Sakyefio, 2020).

All these factors and the likely impact they may have on the outcome of the 2020 election can be broadly subsumed under the rational choice theory of voting behavior where the electorate measure the personal or developmental benefits that will result from the way in which they choose to vote. Even the distribution of clientele benefits, the huge dose of monies and other material benefits shared for votes, all come under the rational choice theory. Therefore, the broader assumption of democratic maturity as well as participation is built within the framework of voter rationality and voter independence; either reinforced by the demand for collective development in exchange for the votes of the electorate or the instantaneous demand for individual goodies in return for the votes of the electorate.

However, the unpredictable nature of the so-called "swing" and "undecided" voters, who have over the years delivered electoral victory to one party or the other in Ghana's elections complicates a simplified categorization of the voting behavior. The rationale behind participation in electoral democracies as nascent as Ghana's is influenced by the ever-expanding nature of the concept in contemporary electoral politics (Schedler, 1998). Yet, there seems to be some consensus, at least on two fronts, regarding voter participation in a democracy. The first is the widespread acceptance of the general principle of democratic competition and voting in an election. For Gunther et al 1986 (cited in Schedler, 1998), a democratic dispensation, like Ghana's, is deemed consolidated when all politically significant groups regard its key political institutions as the only legitimate framework for political contestation, and adhere to the democratic rules of the game. The second is the broad acceptance of democracy, specifically electoral democracy, as the new normal for good governance and successful development. These two consensuses, participation and voting in elections, 
promote a greater commitment to democracy, and hence, signify an important trend towards democratic consolidation. Indeed, Diamond (1993, p. 15) acknowledges that widespread support for democracy is popular participation and voting in free and fair democratic elections. These assumptions are more applicable at the macro level than the micro since every election is different and is influenced by different sets of factors. Thereby, the findings discussed above, though peculiar to the 2012 elections, could have a reinforcing effect on the December 7, 2020 Ghanaian general elections.

First, this paper has shown that political competition has come to stay in the Ghanaian electoral politics and participation, via the ritual of voting in elections, which has become the only means of selecting political leaders in Ghana. This signifies greater commitment to the democratic ideals of the Fourth Republican democratic dispensation. Second, the countervailing political power struggle between Akan-Asantes and Ewes will be repeated in the 2020 general elections. The Akan-Asantes dominated political party, the NPP and the Ewe founded NDC will struggle it out on 7 December 2020. As indicated in our findings, the 2012 presidential elections recorded an increased proportion of voter turnout in all the 216 Asante dominated districts against a decreased proportion of voter turnout in all Ewe dominated districts across the country and this was repeated in the 2016 General elections.

Though disputable, a possible reason, among several others, assumed to be the explanation for the decreased proportion of voter turnout in Ewe dominated districts in the 2012 and 2016 elections was the Rawlings factor. An ethnic Ewe himself and founder of the NDC, Jerry John Rawlings has openly vilified the NDC and its leadership in these two major elections and has discouraged, openly or implied, the dominant Ewe group from going out to vote for the party. This is the first time, since the beginning of the Fourth Republic that Ghanaians will be voting without the physical presence of Jerry John Rawlings. There is 
no doubt that even in death, political elites will still exploit his influence for sympathy vote. Yet, the major beneficiary of this sympathy will be determined after the December $7^{\text {th }}$ election: it could go to the NDC, the NPP or the NDP.

Third, household size (average number of members per household in a district) as a determinant of voter turnout in the 2012 presidential election could be intuitive in the sense that it measures relative poverty. With the winning party being the incumbent government at the time, it is fair to assume that increasing incidence of poverty would have some effect on the electability of the candidate. Thus, there was a positive correlation between voter turnout and the number of persons per household in each district in the 2012 presidential elections. The implication of this finding on the 2020 elections is that all things being equal, we expect that improvement in the socioeconomic conditions of average households in each district in Ghana should influence a positive voter turnout,on 7 December, 2020, and vice-versa. Fourth, voter turnout decreased with the proportion of people who were employed, but increased with the unemployed proportion in all the districts in the 2012 elections. The implication is that all things being equal, voter turnout in the 2020 national election will be lower with increasing proportion of people who are employed, but for the unemployed voters, political parties' will compete for their votes because they will turn out in their numbers to vote for a party whose policies approximate their ambitions.

Fifth, there was an inverse relationship between the urban voter and voter turnout in the 2012 presidential elections. We expect this to continue because of urban stress, and especially in this era of COVID-19 pandemic. The implication on the 2020 elections is that, there will be a voter percentage decrease in all the urban centres. Sixth, in the 2012 presidential elections, voter turnout decreased with increasing proportion of age dependency ratio which measures the ratio of proportion of people who are dependants on the workforce in a district in Ghana. A plausible 
outcome suggests that increasing poverty burden discourages participation in voting. The implication for the 2020 election is that improvement in the socio-economic conditions of this group of voters will whip their interest in voting, else the opposite could occur, come 7 December 2020.

Finally, the younger voter population appeared to have no interest in voting as a civic duty in the 2012 presidential elections. This finding corroborates the views of 'generation school' scholars on voter turnout such as Inglehart (1990), Blais (2000), Dalton (2007), Wattenberg (2007) and others. The finding also corroborates 'context school' scholars.' This school of thought argues, among other things, that low level of voter turnout among younger voter population is the result of certain characteristics including the competitiveness of the election and changes in electoral laws (Franklin, 2004; Franklin et al, 2004). The implication of this finding on the December 7,2020 election in Ghana is that changes in electoral laws and the compilation of a new voters' register will negatively affect turnout in the new voter population.

\section{Conclusion and recommendation}

In this paper the determinants of voter participation were identified based on the use of macro-level analysis using aggregate district-level data on the 2012 national presidential election results compiled by the Electoral Commission of Ghana and district-level data on the 2010 National Population Census compiled by the Ghana Statistical Service using the concept of the "average district voter." The macro-level determinants of voter participation and electoral choices were identified and discussed, and were categorised into social, political and economic determinants. The determinants of electoral behaviour established include age, religion, ethnicity, level of education, locality (urban-rural), and disability factors. These factors significantly influenced voter participation in the 2012 Presidential elections. 
The analysis also established two major points. First, ethnic identification with regard to the two major ethnic groups in Ghana - Asantes and Ewes - clearly influences the choice of presidential candidate as well as other electoral variables such as turnout. Asantes and Ewes constitute about 30 percent of the population of Ghana based on the 2010 National Population Census up from 27.5 percent of the population established in the 2000 National Population Census. Secondly, worsening socio-economic conditions played a role in the turnout. This is because large household size and employment groups turned out in their numbers and participated in the 2012 presidential elections. The key recommendation is that any party seeking to win political power in Ghana should pay particular attention to countervailing politics between Asantes and Ewes and improved socio-economic conditions of Ghanaians. The 2020 elections may likely follow the same pattern. 


\section{References}

Abdulai, A. \& Sackyefio, N. (2020). The Uncertainties of Ghana's 2020 Election. African Affairs Ghana Virtual Issue, https://academic. oup.com/AFRAF/pages/ghana-vi

Alidu, S. \& Aggrey-Darkoh, E. (2018). Rational Voting in National Elections: the 2012 and 2016 Elections in Perspective. Ghana Social Science Journal, 15(1): 98-121.

Alidu, S. (2018). A Political Science Analysis of the 2016 Elections. In Friedrich-Ebert-Stiftung (2018) Election 2016.Accra: FriedrichEbert-Stiftung.

Alidu, S. (2017). A Political Science Analysis of the 2012 Elections. In Friedrich-Ebert-Stiftung (2017) Election 2012. Accra: FriedrichEbert-Stiftung.

Alidu, S. (Forthcoming) Balancing the ticket: ethnicity and regional politics in Ghana's Fourth Republic (1992-2016). In Chitando, E. and Kamara, E. (Eds.) (forthcoming) Religion, Identity \& Values: Rethinking Africa's Development. London: Palgrave.

Anaman, K. A. \& Bukari, G.A. (2019). Political economy analysis of the macroeconomic impact of national elections in Ghana during the fourth republican era, 1992 to 2016..Applied Economics and Finance, 6: 28-44.

Anaman, K.A. (2016). Impact of Democratic Political Transition on the Economy of Ghana. In Ninsin, K.A. (Ed.), Issues in Ghanaian Electoral Politics, CODESRIA, Dakar, pp. 133-149.

Anaman, K. A. \& Agyei-Sasu, F. (2012). Impact of Democratic Political Transition on the Performance of Business Firms in Ghana. Economic Papers: A Journal of Applied Economics and Policy, 31: 391-400.

Bachrach, P. (1967). The Theory of Democratic Elitism: A Critique. Boston, Brown.

Blais, A. (2000). To Vote or Not to Vote: The Merits and Limits of Rational Choice Theory. Pittsburgh: University of Pittsburgh Press.

Blais, A., Loewen, P. \& Bodet, M. (2004). Strategic Voting. In J. Vowles, P. Aimer, S. Banducci, J. Karp \& R. Miller (Eds.) Voters Veto. Auckland, Auckland University Press.

Brady, H., Verba, S. \& Lehman Scholzman, K. (2004). Beyond SES: A Resource Model of Political Participation. American Political Science Review, 89, 2.

Bukari, G.A. (2017). Political Economy Analysis of Elections in Ghana's Fourth Republic (1992 to 2016). Doctor of Philosophy Thesis, Accra, Ghana: University of Ghana.

Brierly, S. \& Kramon, E. (2020). Party Campaign Strategies in Ghana: Rallies, Canvassing and Handouts. African Affairs, 11/00; 1-26. 
Chandra, K. (2009). Why Voters in Patronage Democracies Split Their Tickets: Strategic Voting in Ethnic Parties. Electoral Studies, 28(1): 21-32.

Cheeseman, N. \& Ford, R. (2007). Ethnicity as Political Cleavage. Afrobarometer Working Paper No. 83.

Dalton, R. J. (2007). The good citizen: How a younger generation is reshaping American politics. Washington, DC: CQ Press. Diamond, L. (1993). The Globalization of Democracy. Boulder: Lynne Rienner.

Downs, A. (1957). An Economic Theory of Democracy. New York: Harper and Row

Franklin, M. (2004). Voter Turnout and the Dynamics of Electoral Competition in Established Democracies since 1945. Cambridge: Cambridge University Press.

Franklin, M. N. (2004). Voter turnout and the dynamics of electoral competition in established democracies since 1945. Cambridge, UK: Cambridge University Press.

Franklin, M. N., Lyons, P., \& Marsh, M. (2004). Generational basis of turnout decline in established democracies. Acta Politica, 39: 115151.

Frempong, A. K. D. (2006). Ethnicity, Democracy and Ghana's Election 2004. In Boafo-Authur, K. (Ed.) Voting for Democracy in Ghana (Thematic Studies). Accra: Freedom Publications, Legon, Ghana, pp.157-186.

Huntington, S. P. (1991). The Third Wave: Democratization in the Late Twentieth Century. Norman, OK: University of Oklahoma Press.

Inglehart, R. (1990). Culture shift in advanced industrial society. Princeton, NJ: Princeton University Press.

Lindberg, S. I. \& Morrison, M.K.C. (2008). Are African Voters Really Ethnic or Clientelistic? Survey Evidence from Ghana. Political Science Quarterly, 123(1): 95-122.

Lindberg, S. I. \& Morrison, M.K.C. (2005). "Exploring Voter Alignments in Africa: Core and Swing Voters in Ghana." Journal of Modern African Studies, 43(4): 1-22.

Lindberg, S.I. (2013). Have the cake and eat it: the rational voter in Africa. Party Politics, 19(6): 945-961.

McAllistair, I. (1992). Political Behaviour. Melbourne: Longman Cheshire. Norris, P. (2002). Democratic Phoenix. New York: Cambridge University. Riker, W. \& Ordeshook, C. (1968). A Theory of the Calculus of Voting. In American Political Science Review. 62: 25-42.

Rosenstone, S. \& Hansen, J. (1996). Mobilization, Participation and Democracy in America. New York: Longman.

Scheduler, A. (1998). What is Democratic Consolidation? Journal of Democracy. 5: 91-107.

Legon Journal of the Humanities 31.1 (2020) 
Alidu, S. M. \& Bukari, G. A../Legon Journal of the Humanities Vol. 31.1 (2020)

Schumpeter, J. (1954). Capitalism, Socialism \& Democracy. London: Unwin University Books.

Tocqueville, A. (1990). Democracy in America. New York: Vintage Books. Vowles, J. (1995). Electoral Participation. In J. Vowles, P. Aimer, H. Catt, J. Leman, R. Miller (Eds.) Towards Consensus. Auckland: Auckland University Press.

Wattenberg, M. P. (2007). Is voting for young people? New York, NY:

Pearson Longman 